"FINDLEY, J. S. 1955. Speciation of the wandering shrew. University of Kansas, Museum of Natura! History, Lawrence, Kansas. Vol. 9. 68 p.

"KENDEIGH, S. C. 1961. Animal ecology. Prentice-Hall, Inc. Englewood Cliffs, N.J. 468 p.

${ }^{4}$ ROWE, J. S. 1972. Forest regions of Canada. Canadian Forestry Service, Department of the Environment. Information Canada, Ottawa. $172 \mathrm{p}$.

'SALT, J. R. 1975. The Soricidae of Alberta - a review. Unpublished manuscript. Provincial Museum of Alberta.

${ }^{6}$ SOPER, J. D. 1964. Mammals of Alberta. Department of Industry and Development, Queen's Printer, Edmonton. 402 p.

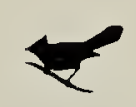

\section{COUGAR SHOT AT CUTKNIFE, SASK.}

\section{By TOM WHITE, 2580 Retallack St., Regina, Sask.}

John Reinboldt went out to check the farm fence at about 9:30 a.m., November 15, 1975, when he saw a cougar moving in long leaps about 250 yards away. It was near the cattle so he went back for his dog and gun. He released his German shepherd which flushed the cougar out of the brush and pursued it for a quarter mile. The cougar would run, pause, look back and then run again. Mr. Reinboldt walked to within 30 yards of where the cougar was facing the dog and shot it. One hundred yards from where the cougar was first sighted, a deer was found with its belly slit open and the shoulder and neck cut. The cougar was obtained by Ken Smith, Conservation Officer at North Battleford, and given to the Museum of Natural History in Regina. It was a female weighing 125 pounds with a body 50 inches from tip of nose to base of tail and a further 27 inches for the tail.

Rabbit tracks in the snow.

Lorne Scott
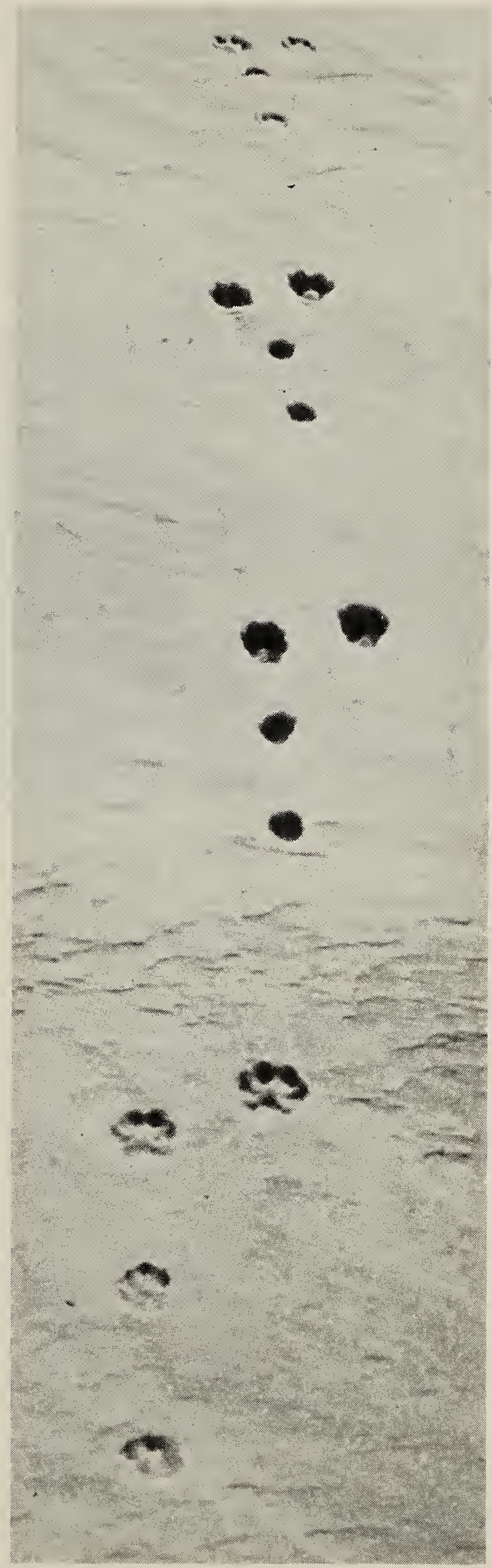